原 著論 文

マウスガードシートの形状が成形後マウスガードの厚さに与える影響

高橋 睦 ${ }^{\mathrm{a}}$, 小出 馨 ${ }^{\mathrm{a}}$, 水橋 史 $^{\mathrm{a}}$, 森田 修已 ${ }^{\mathrm{b}}$

\title{
Thickness of Mouthguard Sheet after Formation Based on the Shape of the Mouthguard Sheet
}

\author{
Mutsumi Takahashi, DDS, $\mathrm{PhD}^{\mathrm{a}}$, Kaoru Koide, DDS, $\mathrm{PhD}^{\mathrm{a}}$, Fumi Mizuhashi, DDS, $\mathrm{PhD}^{\mathrm{a}}$ \\ and Osami Morita, DDS, $\mathrm{PhD}^{\mathrm{b}}$
}

\section{抄 録}

目的：マウスガード装着による外傷予防効果は，マウスガードシートの材質や付与される厚さに大きく依 存する，本研究では，シートの形状による吸引成形後マウスガードシート各部の厚さについて，加熱状態 の影響とともに検討を行った。

方法：材料は，溝付きのステップタイプのマウスガードシート (インパクトガード ${ }^{\circledR}$ ) および同質材料の 溝のないフラットなシートを使用し，このシートに $10 \mathrm{~mm}$ 四方の格子を記入して測定部とした．厚さの 測定は各格子の厚さをメジャリングディバイスを用いて計測した。作業用模型は, 上顎中切歯切縁で 20 $\mathrm{mm}$ ，上顎第一大鼠近心煩側咬頭で $15 \mathrm{~mm}$ の高さにトリミングしたものを使用した。成形には吸引型 成型器を用い，加熱状態はシート基底面がクランプから $10 \mathrm{~mm}, 15 \mathrm{~mm}$ および $20 \mathrm{~mm}$ 降下した時点と した。 分析は, シートの形状と加熱状態によるシートの厚さの変化率の違いについて，二元配置分散分析 を用いて行った。

結果：シートの形状による厚さの違いは，前歯部および臼歯部で有意差が認められ，溝付きシートの方が 厚さの減少率は小さかった，加熱状態による厚さの違いは，前歯部，口蓋部および臼歯部において $10 \mathrm{~mm}$ と 20mm の間で有意差が認められ，加熱が進むほど厚さの減少率は大きかった。

結論：吸引成形後マウスガードの厚さはシートの形状と加熱状態に影響を受け，溝付きシートを用いた方 が前歯部と臼歯部の厚さを確保できることが明らかとなった。

和文キーワード

マウスガード，厚さ，シートの形状，加熱状態

\section{I。緒言}

近年のスポーツ競技の多様化によりスポーツ時の顎顔 面領域の外傷予防やスポーツパフォーマンスの向上を目 的としてマウスガードが普及してきており，その効果や 安全性を大きく左右するのがマウスガードの厚さや材質 であることが報告されている ${ }^{1-7)}$ 。 マウスガードシート の材質はエチレン酢酸ビニル樹脂，オレフィン系熱可塑
性エラストマー，およびスチレン系熱可塑性エラストマ 一に大別され，エチレン酢酸ビニル樹脂は軟化温度が低 く利用範用が広いことや安価であることから，最も多く 使用されている。 また，オレフィン系熱可塑性エラスト マーは加工性が良く熱溶着性や耐候性に優れる一方，耐 摩耗性が不十分であり，スチレン系熱可塑性エラストマ 一は軟化温度が高く耐候性が劣る一方, 柔軟性や弾力性 に優れる性質を持つ ${ }^{8,9)}$.

熱可塑性シートを用いてマウスガードを製作する際に

\footnotetext{
${ }^{a}$ 日本歯科大学新潟生命歯学部歯科補綴学第 1 講座

${ }^{\mathrm{b}}$ 日本歯科大学

${ }^{\text {a }}$ Department of Removable Prosthodontics, The Nippon Dental University School of Life Dentistry at Niigata

${ }^{\mathrm{b}}$ The Nippon Dental University

受付 : 2010 年 9 月 6 日/受理 $: 2010$ 年 10 月 15 日
}

Received on September 6, 2010 /Accepted on October 15, 2010 
は，成形時にシートが模型に圧接され，部分的に引き延 ばされて厚さが変化する。われわれはこれまでに吸引成 形後のマウスガードシートの形状変化について検討を行 い，作業用模型やシートの条件によって前歯部の厚さが 最も影響を受けやすく，適切な効果を発揮するための厚 さの確保が困難であることを明らかにした ${ }^{10-16)}$ 。した がって，このことを考慮して適正な厚さを確保するため の使用材料の選択，製作方法の検討を行うことが重要と 考える.

現在，高い衝撃吸収能と耐久性を有するポリオレフィ ンーポリスチレンブロック共重合体シートが市販されて いる。このシートは溝が付与されたステップタイプで, 一回の成形で前歯部の厚さを充分に確保できるとされて いる. しかしながら, シートに付与された溝が成形後マ ウスガードの厚さにどのように影響を与えるかは明らか にされていない，本研究では，シートの形状による吸引 成形後マウスガードの厚さについて, 加熱状態の影響と ともに検討を行った。

\section{II. 研究方法}

材料は，溝付きマウスガードシート（インパクトガー ド ${ }^{\circledR}, 129 \times 129 \times 4.0 \mathrm{~mm}$ ，ステップ部 $3.0 \mathrm{~mm}$, クリア，ジーシー，東京，日本）(以下，IM-G)，およ び溝のないフラットな試作マウスガードシート（129 $\times 129 \times 4.0 \mathrm{~mm}$ ，クリア，ジーシー）（以下， IM-F） を使用した（図 la, b)。このシートに油性マーカー (A-

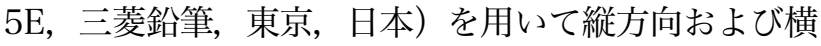
方向に 11 個の $10 \mathrm{~mm}$ 四方の格子線（線の太さ, 約 $0.5 \mathrm{~mm}$ ) を記入し計測部とした。作業用模型は上顎有 歯顎模型（500A，ニッシン，京都，日本）を複製用の シリコンラバー印象材 (Correcsil ${ }^{\circledR}$, 山八歯材工業, 愛 知，日本）を用いて印象採得後，硬質石膏（ニュープラ

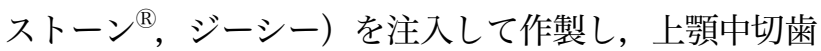
切縁で $20 \mathrm{~mm}$, 上顎第一大臼歯近心㚘側咬頭で $15 \mathrm{~mm}$ の高さにトリミングしたものを使用した（図 $2 a, b)$.

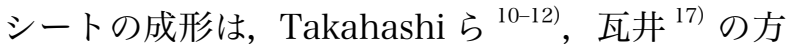
法に準じて, 吸引型成型器（ウルトラフォーマー ${ }^{\circledR}$, Ultradent, Utah, USA）を用いて行った。成形時の模 型の位置は，模型の前歯部が吸引面の中央となるよう設 置した. 成型器への IM-G の設置は, シートの溝のある 側を前歯部側上面とした。成形は，シートの最も下垂し た部位が基底面から $10 \mathrm{~mm} ， 15 \mathrm{~mm}$ ，および $20 \mathrm{~mm}$ 降下した時点（以下，c-10, c-15, c-20）で吸引圧接 して行った. シートの降下距離は, 三次元座標測定器 (No. 192-201, Mitutoyo, 神奈川, 日本) にレーザー
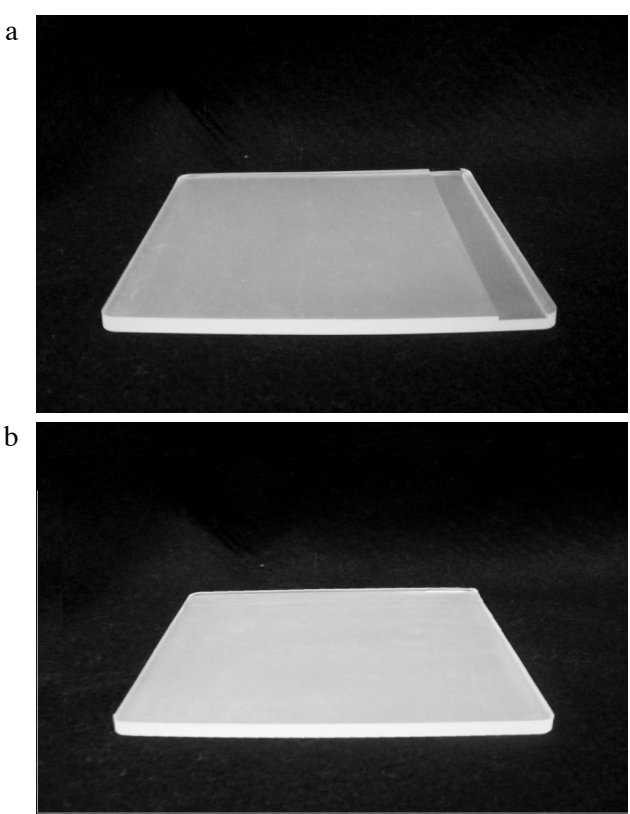

図 1 Mouthguard sheet a: Grooved sheet b: Flat sheet マウスガードシート $\mathrm{a}$ ：溝付きシート $\mathrm{b} ：$ フラットなシート

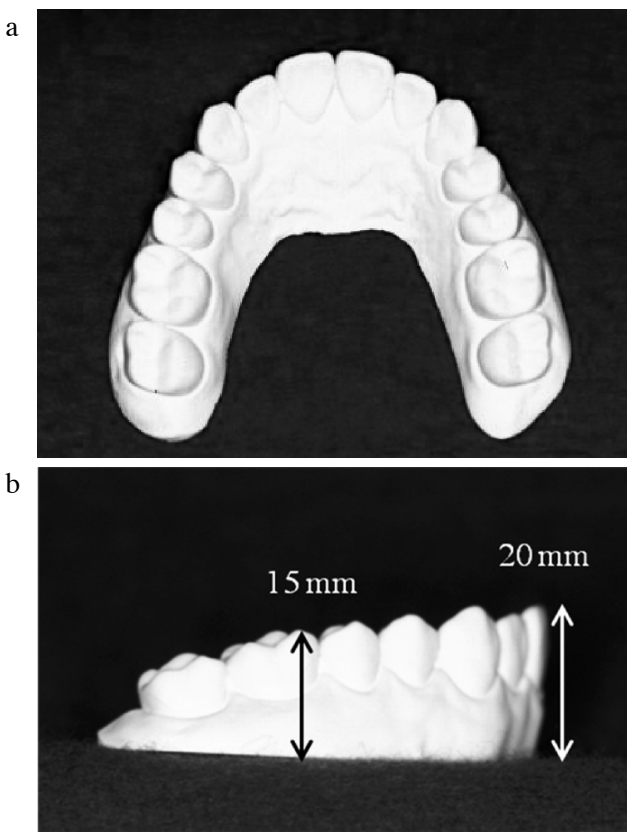

図 2 Plaster cast a: Occlusal surface appearance b: Lateral appearance 作業用模型 $\mathrm{a}$ ：咬合面観 $\mathrm{b} ：$ 側面観 
ポインターを固定して測定した。圧接は 2 分間とし, 放冷は空調のきいた室温（約 $24.5^{\circ} \mathrm{C}$ ）にて 3 時間以上 とした，試料は，IM-Gおよび IM-F において各加熱状 態 c-10，c-15，c-20 で 6 個ずつ，計 36 個製作した. 圧接されたシートと模型の位置関係を模式図に示す（図 3). 模型に圧接されたシートの前歯部相当部は $\mathrm{E} ; 4,5$, $\mathrm{F} ; 4,5, \mathrm{G} ; 4,5$ ，口蓋部相当部は $\mathrm{E} ; 6,7, \mathrm{~F} ; 6,7, \mathrm{G}$; 6,7，臼歯部相当部は C; 6-9，D；6-9，H；6-9，I；6-9 となった。

マウスガードシートの厚さの測定は，メジャリングデ イバイス ${ }^{\circledR}$ (21-111, YDM, 東京, 日本) を用いて行い, シートが模型の前歯部，口蓋部および臼歯部に圧接され た部位は, 図 3 に示した前歯部 6 箇所，口蓋部 6 箇所, および臼歯部 16 箇所とした．測定部位はシートに記入 した各格子線上とし, 縦方向, 横方向とも任意に 5 等 分した 5 箇所とし，各格子を囲む 4 本の線上の厚さの 平均值を算出して格子の厚さとした，各格子の厚さの変 化率を計算式 [変化率 $(\%)=$ (成形後の厚さ一成形前 の厚さ）：成形前の厚さ $\times 100]$ により算出し，分析に 用いた。

統計処理には, 統計用解析ソフト (SPSS 17.0, SPSS JAPAN，東京，日本）を使用した。 マウスガー ドシートの形状および加熱状態によるシートの厚さの変 化率の違いについて，正規性の検定には Shapiro-Wilk 検定を，等分散性の検定には Levene 検定を用い，各 項目において正規性および等分散性が示されたため，二 元配置分散分析後, Scheffé 法を用いて多重比較法によ る検定を行った。

\section{III. 結 果}

吸引成形後のマウスガードシートを図 $4 \mathrm{a} \sim \mathrm{f}$ に示す. シートの形状および各加熱状態における IM-G および IM-F の厚さの変化率の平均值を模式図に示す（図 $5 \mathrm{a}$ 〜 f). 厚さが減少する範囲はいずれの条件でも同一で あるが，前歯部および臼歯部のシートの厚さの減少率は 加熱状態が進むと大きくなった。 また，シートの形状で 比較すると，c-15 および c-20において，IM-Gでは IM-F に比較して模型に圧接される部分の厚さの減少率 が小さかった。

シートの形状による二元配置分散分析および多重比較 の結果を表 1 に, 加熱状態による二元配置分散分析お よび多重比較の結果を表 2 に示す。シートの形状によ る違いは，前歯部では c-15において，臼歯部では c-15，c-20 において，IM-G と IM-F の間で有意差が 認められ，溝付きシートの方が厚さの減少率が小さかっ

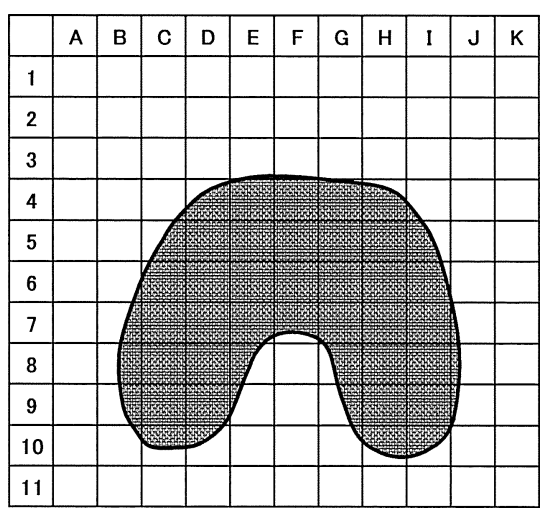

図 3 The relationship of the position between the mouthguard sheet and the plaster cast after forming

The gray area indicates the area of the sheet mounted on the plaster cast.

成形後のマウスガードシートと作業用模型との位置 関係

シートの黒色部が模型圧接部.

た，加熱状態による違いは，前歯部および口蓋部におい て，IM-G と IM-F ともに c-10 と c-20 の間， 臼歯部に おいて IM-F の c-10 と c-20 の間で有意差が認められ, 加熱が進むほどシートの厚さの減少率は大きかった。

\section{IV. 考 察}

熱可塑性シートを軟化・圧接して成形を行うマウスガ 一ド材では，部分的に引き延ばされて厚さか湾化するた め，成形後の厚さを完全にコントロールすることは困難 である. シートの材質や厚さ，作業用模型の形態や設置 角度, 成型器の種類が成形後マウスガードの厚さに大き

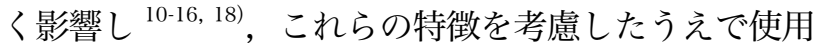
材料や製作方法を選択することが望ましい.

現在市販されているジーシー社製インパクトガード ${ }^{\circledR}$ は，高い衝撃吸収能を示す材質であることと，シートに 溝が付与されたステップタイプの形状であることが特長 である，成形時にはシートのステップ部が延び，シング ルレイヤーでも前歯部の厚さを充分に確保できるとされ ている。しかし，マウスガードの厚さは成形条件に大き く影響を受けることから，シートの形状により適切な成 形方法も異なると考えられる。本研究では，シートの形 状が吸引成形後マウスガードの厚さに与える影響につい て，溝付きのステップタイプのシートと同質材料のフラ ットなシートを用いて，加熱状態の影響とともに比較検 討を行った。

マウスガード製作時の作業用模型の条件は，中切歯の 歯軸が模型基底面に対して垂直で前歯部唇面のアンダー 


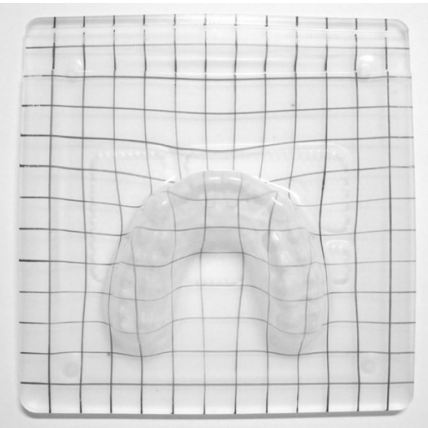

c

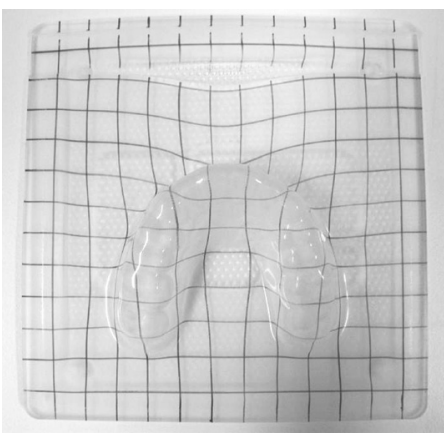

e

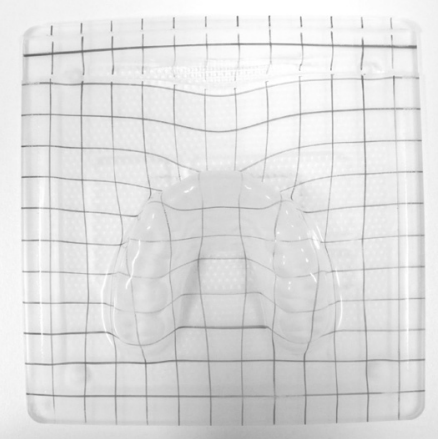

b

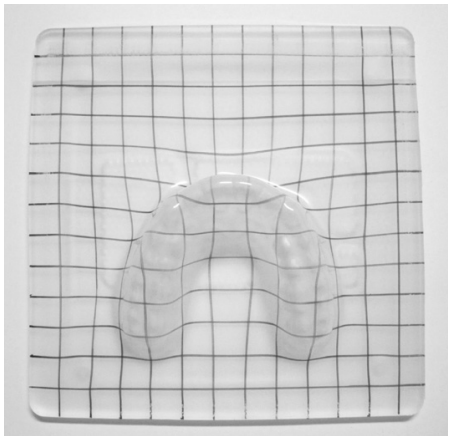

d

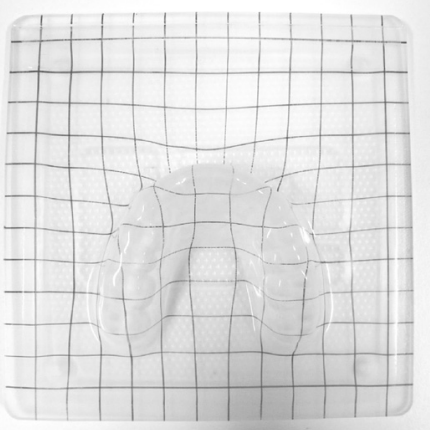

f

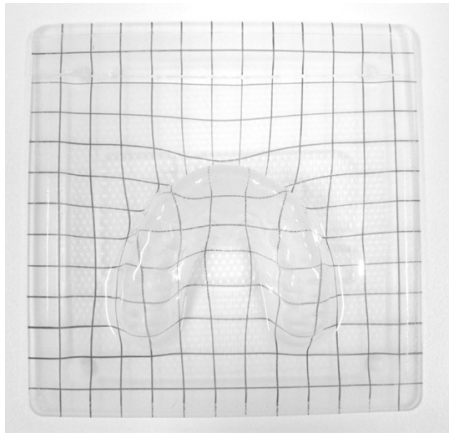

図 4 Mouthguard sheet after vacuum forming

a: Heating condition was $10 \mathrm{~mm}$ of grooved sheet (c-10, IM-G) b: Heating condition was $10 \mathrm{~mm}$ of flat sheet (c-10, IM-F)

c: Heating condition was $15 \mathrm{~mm}$ of grooved sheet (c-15, IM-G)

d: Heating condition was $15 \mathrm{~mm}$ of flat sheet (c-15, IM-F)

e: Heating condition was $20 \mathrm{~mm}$ of grooved sheet (c-20, IM-G)

$\mathrm{f}$ : Heating condition was $20 \mathrm{~mm}$ of flat sheet (c-20, IM-F)

吸引成形後のマウスガードシート

$\mathrm{a}$ ：溝付きシート，加熱状態 $10 \mathrm{~mm}$

$\mathrm{b}$ ：フラットなシート, 加熱状態 $10 \mathrm{~mm}$

$\mathrm{c}$ ：溝付きシート, 加熱状態 $15 \mathrm{~mm}$

$\mathrm{d}$ ：フラットなシート, 加熱状態 $15 \mathrm{~mm}$

$\mathrm{e}$ : 溝付きシート, 加熱状態 $20 \mathrm{~mm}$

$\mathrm{f} ：$ フラットなシート, 加熱状態 $20 \mathrm{~mm}$

カットがないこと, 模型基底面が水平であること, さら に可及的に模型の高さを減じることである ${ }^{1,12,19,20-22) . ~}$ 本研究で使用した上顎有歯顎模型で上記の条件を可能な 限り満たすように作業用模型のトリミングを行った結 果, 上顎中切歯切縁で $20 \mathrm{~mm}$, 上顎第一大鼠歯近心㚘 側咬頭で $15 \mathrm{~mm} の$ 高さとなった。
吸引型成型器は，配管が不要なため設置場所を選ばな いこと，また安価であり操作が簡便である一方，圧接力 が弱いことが欠点である ${ }^{23,24)}$ 。このため，シートの材 質が成形性に大きく影響し，十分な成形を行えない場合 があるが，本研究で用いたポリオレフィンーポリスチレ ンブロック共重合体シートは高い細部再現性と柔軟性を 


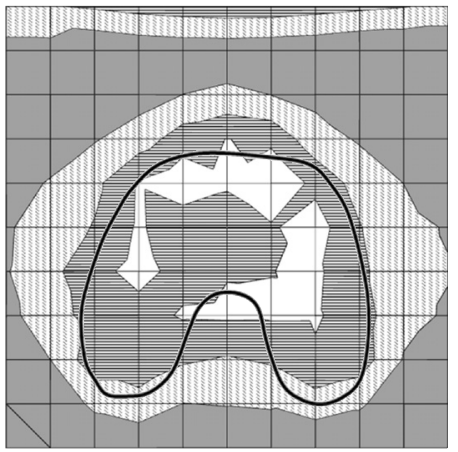

c

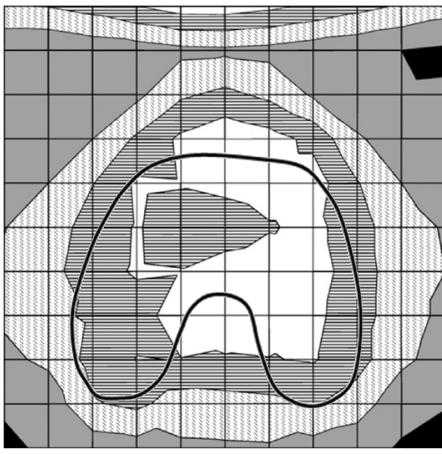

$\mathrm{e}$

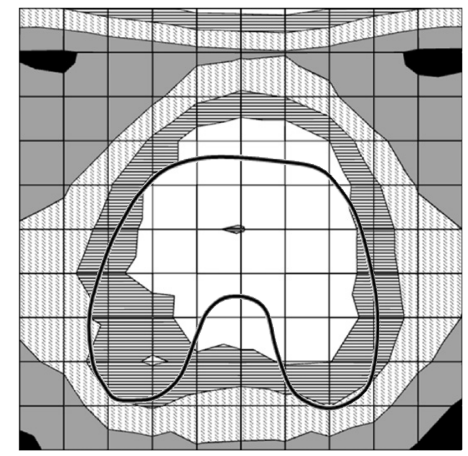

- $0 \sim 10$

$\square-10 \sim 0$

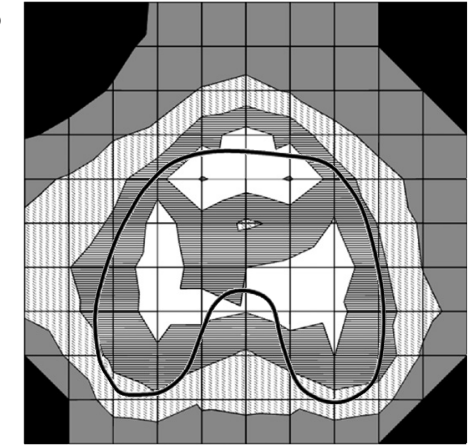

d

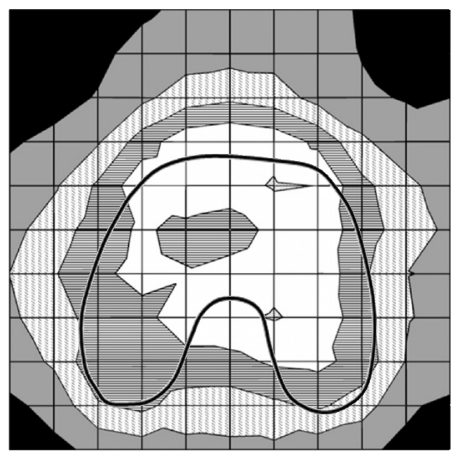

$\mathrm{f}$

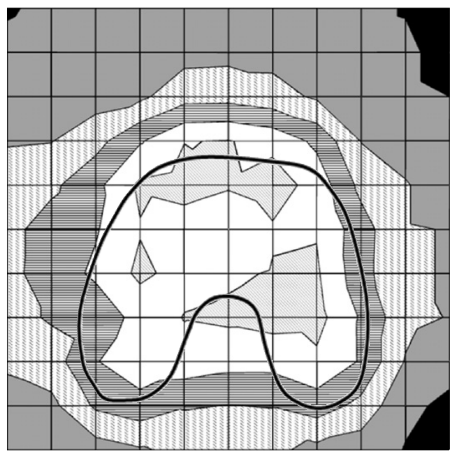

目 $-30 \sim-20$

$\square-40 \sim-30$

$\square-50 \sim-40$

$(\%)$

図 5 The ratio of change of the thickness in each cross stripe area a: Heating condition was $10 \mathrm{~mm}$ of grooved sheet (c-10, IM-G) b: Heating condition was $10 \mathrm{~mm}$ of flat sheet (c-10, IM-F) c: Heating condition was $15 \mathrm{~mm}$ of grooved sheet (c-15, IM-G) $\mathrm{d}$ : Heating condition was $15 \mathrm{~mm}$ of flat sheet (c-15, IM-F) e: Heating condition was $20 \mathrm{~mm}$ of grooved sheet (c-20, IM-G) $\mathrm{f}$ : Heating condition was $20 \mathrm{~mm}$ of flat sheet (c-20, IM-F) 各格子の厚さの変化率

$\mathrm{a}$ ：溝付きシート，加熱状態 $10 \mathrm{~mm}$

$\mathrm{b}$ ：フラットなシート，加熱状態 $10 \mathrm{~mm}$

$\mathrm{c}$ ：溝付きシート，加熱状態 $15 \mathrm{~mm}$

$\mathrm{d} ：$ フラットなシート, 加熱状態 $15 \mathrm{~mm}$

$\mathrm{e}$ ：溝付きシート，加熱状態 $20 \mathrm{~mm}$

$\mathrm{f}$ : フラットなシート, 加熱状態 $20 \mathrm{~mm}$

有することから，吸引型成型器を用いても適合性は良好 であると考えられる。吸引型成型器を用いる場合には，
成形のタイミングをシートの降下具合により判断する方 法が主に用いられている ${ }^{10-16,18)}$. 本研究で使用したシ 
表 1 Results of the two-way ANOVA and Scheffé test based on the shape of the mouthguard sheet シートの形状による二元配置分散分析および Scheffé 法の結果

\begin{tabular}{|c|c|c|c|c|c|c|c|}
\hline \multirow{2}{*}{ Measurement } & \multirow{2}{*}{ Heating condition } & \multicolumn{2}{|c|}{ IM-G } & \multicolumn{2}{|c|}{ IM-F } & \multirow{2}{*}{ (IM-G)-(IM-F) } & \multirow{2}{*}{$p$-value } \\
\hline & & Mean & SD & Mean & SD & & \\
\hline \multirow[t]{3}{*}{ Anterior teeth } & c-10 & -31.9 & 2.4 & -34.2 & 2.2 & 2.30 & 0.14 \\
\hline & $c-15$ & -33.4 & 2.4 & -38.6 & 2.3 & 5.17 & $<0.01^{* *}$ \\
\hline & $c-20$ & -38.2 & 2.4 & -41.3 & 3.0 & 3.11 & 0.13 \\
\hline \multirow[t]{3}{*}{ Palate } & $c-10$ & -26.4 & 3.5 & -26.0 & 4.0 & -0.32 & 0.83 \\
\hline & $c-15$ & -30.1 & 3.5 & -31.1 & 2.3 & 1.06 & 0.17 \\
\hline & $c-20$ & -35.3 & 2.7 & -36.7 & 3.4 & 1.45 & 0.14 \\
\hline \multirow[t]{3}{*}{ Posterior teeth } & $c-10$ & -27.1 & 4.4 & -28.1 & 5.0 & 0.97 & 0.19 \\
\hline & $c-15$ & -27.6 & 4.1 & -29.5 & 4.7 & 1.90 & $<0.01^{* *}$ \\
\hline & $c-20$ & -29.1 & 4.9 & -33.4 & 5.0 & 4.36 & $<0.001^{* *}$ \\
\hline
\end{tabular}

${ }^{* *} p<0.01$

表 2 Results of the two-way ANOVA and Scheffé test based on the heating condition of the mouthguard sheet

加熱状態による二元配置分散分析および Scheffé 法 の結果

\begin{tabular}{|c|c|c|c|c|}
\hline \multirow{2}{*}{$\begin{array}{c}\text { Measurement } \\
\text { Anterior teeth }\end{array}$} & \multirow{2}{*}{$\frac{\text { Shape of the sheet }}{\text { IM-G }}$} & \multicolumn{2}{|c|}{ Heating condition } & \multirow{2}{*}{$\begin{array}{l}p \text {-value } \\
0.81\end{array}$} \\
\hline & & $\mathrm{c}-10$ & c-15 & \\
\hline & & & $c-20$ & $0.04^{*}$ \\
\hline & & $c-15$ & $c-20$ & 0.12 \\
\hline & IM-F & c-10 & $c-15$ & 0.24 \\
\hline & & & $c-20$ & $0.03^{*}$ \\
\hline & & $c-15$ & $c-20$ & 0.53 \\
\hline \multirow[t]{6}{*}{ Palate } & IM-G & $c-10$ & $c-15$ & 0.39 \\
\hline & & & $c-20$ & $0.01^{*}$ \\
\hline & & $c-15$ & $c-20$ & 0.18 \\
\hline & IM-F & $c-10$ & $c-15$ & 0.18 \\
\hline & & & $c-20$ & $<0.01^{* *}$ \\
\hline & & c-15 & $\mathrm{c}-20$ & 0.13 \\
\hline \multirow[t]{6}{*}{ Posterior teeth } & IM-G & $c-10$ & $c-15$ & 0.96 \\
\hline & & & $c-20$ & 0.49 \\
\hline & & $c-15$ & $c-20$ & 0.67 \\
\hline & IM-F & c- 10 & $c-15$ & 0.83 \\
\hline & & & $c-20$ & $0.04^{*}$ \\
\hline & & $c-15$ & $c-20$ & 0.14 \\
\hline
\end{tabular}

${ }^{* *} p<0.01,{ }^{*} p<0.05$

ートは，メーカー指定ではシートが基底面から $15 \mathrm{~mm}$ 降下した時点が適切な加熱状態とされている。 そこで, 本研究では加熱状態による影響を比較するため, 成型器 の予備加熱は行わず，シートが基底面から $10 \mathrm{~mm}$, $15 \mathrm{~mm}, 20 \mathrm{~mm}$ 降下した時点で吸引成形した際のマ ウスガードの厚さを比較した。通常，成型器によりマウ スガードシートを加熱する際，フラットなシートの場合 にはシート周辺に比べて中央部の軟化が速いが ${ }^{25)}$ ，溝 付きシートの場合にはステップ部の軟化が速い.このた め，加熱によりフラットなシートでは中央部から下垂し てくるが，溝付きシートではシート中央部よりやや前方
から下垂してくる.したがって，本研究においてはシー 卜の最も下垂した部位を基底面からの降下距離とし，加 熱状態を計測した。シートを加熱すると，約 2 分後に 下垂が始まり，10 mm，15 mm，20 mm 降下するま での加熱時間は両試料とも約 3 分 40 秒，約 4 分，約 4 分 15 秒であった。また，このときのシート中央部の表 面温度を放射温度計により測定した結果，両試料とも下 垂が始まる約 2 分後にはシート上面で約 $120.0^{\circ} \mathrm{C}$ ，下 面で約 $65.0^{\circ} \mathrm{C}$ であった. $10 \mathrm{~mm}, 15 \mathrm{~mm}, 20 \mathrm{~mm}$ 降下するまでの温度は，上面ではいずれの加熱状態にお

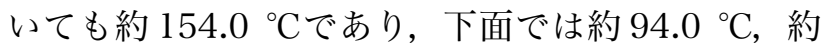
$104.5{ }^{\circ} \mathrm{C}$, 約 $104.5{ }^{\circ} \mathrm{C}$ であった。 これらのことから, 各加熱状態における溝付きシートとフラットなシートの 軟化状態，および加熱状態 $15 \mathrm{~mm}$ と $20 \mathrm{~mm}$ のシート の軟化状態に大差はないものと推察される。

シートに記入した格子線の延びから，加熱状態 15 $\mathrm{mm}$ および $20 \mathrm{~mm}$ において溝付きシートではステッ プ部で模型方向にシートが引き延ばされ，フラットなシ ートと比較して前歯部より前方で縦方向に延びている様 子が観察される。シートの形状による厚さの減少率を比 較すると, 溝付きシートとフラットなシートでは厚さの 減少する範囲は同じ傾向を示すが，前歯部，臼歯部に圧 接される部分を中心に溝付きシートに比べてフラットな シートの方が減少率は大きくなった，成形時にマウスガ ードシートが模型に圧接される際，前歯部では作業用模 型に対して垂直方向となる縦方向の延びの変化が大きく なるため ${ }^{10-16)}$ ，厚さが減少すると考えられる，溝付き シートではステップ部の厚さが $3 \mathrm{~mm}$ であり, 他の部 位と比較して熱伝導性が高く軟化速度が速いため，成形 時にはステップ部が模型方向に引き延ばされることによ つて前歯部よりも前方のシートが延び，前歯部の厚さの 減少が抑えられたと考えられる。また，シートの軟化が 
進むと自重によりシートは下方へ垂れ下がり，このとき に引き延ばされて厚さが減少する ${ }^{26)}$. 溝付きシートで はステップ部の軟化が速いため, ステップ部以外の範囲 ではシートの自重による厚さの減少が抑えられ，臼歯部 の厚さの減少率が小さくなったと考えられる．多重比較 法によりシートの形状による影響を比較したところ，前 歯部では加熱状態が $15 \mathrm{~mm}$, 臼歯部では加熱状態が $15 \mathrm{~mm}$ と $20 \mathrm{~mm}$ の条件で有意差が認められた。この ことから, 加熱状態が $15 \mathrm{~mm}$ 以上進行すると, フラッ トなシートと比較して溝付きシートでは, より前歯部の 厚さを確保でき，臼歯部においても厚さの減少を抑えら れることが明らかとなった。

シートの加熱状態による厚さの減少率を比較すると, 両試料とも加熱が進むにつれて模型に圧接される範囲を 中心に厚さが減少した. 前歯部および臼歯部の厚さの減 少率は, 加熱状態による有意差は認められなかったが, 加熱状態が $15 \mathrm{~mm}$ から $20 \mathrm{~mm}$ に進むと溝付きシート ではー 30 〜 -40\%の範囲が広くなるが，フラットなシ ートではー40\%以上の範囲が認められ，厚さが大きく 減少する傾向が示された。加熱状態が $15 \mathrm{~mm}$ と 20 $\mathrm{mm}$ の際，シート上面と下面の表面温度は同一であっ たため, シートの軟化状態に大差はないものと考えられ る.このため, 加熱状態が $20 \mathrm{~mm}$ のシートにおける厚 さの減少率は, シートの自重による影響と推測される. 多重比較法により各加熱状態による影響を比較したとこ ろ, 溝付きシートでは前歯部，口蓋部において，フラッ トなシートでは前歯部, 口蓋部, 臼歯部において加熱状 態が $10 \mathrm{~mm}$ から $20 \mathrm{~mm}$ へ進んだ際に有意差が認めら れた. しかし, 加熱状態が $10 \mathrm{~mm}$ では模型のアンダー カットまでシートが圧接されず歯䅡部の適合が悪いた め, 維持力がそしく, 装着感に影響を与えることが予測 された。このことから，シートの加熱状態は $15 \mathrm{~mm}$ 以 上が適当と考えられる。

以上の結果より, 吸引成形後マウスガードシートの厚 さはシートの形状によって異なることが明らかとなっ た。 また, 加熱状態による違いも認められ, シートの降 下距離を $15 \mathrm{~mm}$ に設定し, 溝付きシートを用いること によって前歯部および臼歯部の厚さを確保できることが 示唆された。

\section{V. 結 論}

マウスガードシートの形状による吸引成形後マウスガ ードの厚さについて, 加熱状態の影響とともに検討を行 い，以下の結論を得た。

1. シートの形状による違いについて, 前歯部では加
熱状態を $15 \mathrm{~mm}$ に設定した条件で， 臼歯部では 加熱状態を $15 \mathrm{~mm}$ および $20 \mathrm{~mm}$ に設定した条 件で, 溝付きシートの方がフラットなシートと比 較して厚さの減少率は有意に小さかった。

2. 加熱状態による違いについて, 前歯部および口蓋 部において溝付きシートとフラットなシートでは 加熱状態が $10 \mathrm{~mm}$ と $20 \mathrm{~mm}$ の間で，臼歯部に おいてフラットなシートでは加熱状態が $10 \mathrm{~mm}$ と $20 \mathrm{~mm}$ の間で有意差が認められ, 加熱が進む ほどシートの厚さの減少率は大きかった。

\section{文献}

1）前田芳信，安井利一，米畑有理、マウスガード製作マニ ュアルースポーツ歯学への誘い一. 東京: クインテッセ ンス出版 ; 2001, 184-185.

2) Dennis NR（石上惠一，前田芳信). Advance in sports dentistry（アドバンス・スポーツ歯学. 東京 : 医 学情報社；2001，31-44.), 2000.

3）石島 勉, 斎藤 実, 朝比奈義明, 金澤 毅, 今村 円, 後藤 洋ほか. 口腔領域のスポーツ外傷とマウスガード に関する調査. 愛院大歯誌 1988; 27: 673-686.

4) McNutt T, Shannon SW, Wright JT, Feinstein RA. Oral trauma in adolescent athletes $-\mathrm{A}$ study of mouth protectors-. Pediatr Dent 1989; 11 : 209-213.

5) Johnsen DC, Winters JE. Prevention of intraoral trauma in sports. Dent Clin North Am 1991; 35: 657-666.

6）前田芳信，松田信介．使ってもらえるマウスガードを作 るために. 科学的根拠に基づいたマウスガード製作法. 歯界月報 2007; 667: 28-35.

7） 月村直樹, 武田友孝, 小川 透, 中島一憲, 内藤 薫, 黒川勝英ほか. マウスガードの衝撃吸収能について。 日 大歯学 2004; 78: 115-120.

8）竹内正敏。マウスガードの製作・調整法. 日本スポーツ 歯科医学会編, スポーツ歯科臨床マニュアル, 東京 : 医 学情報社 ; 2007, 61-63.

9）竹内正敏, 都賀谷紀宏. 口腔内装置作製のためのサーモ フォーミング徹底活用一マウスガード，スプリント，ド ラッグデリバリートレー, インプラント用テンプレート， 可撤式矯正装置 etc. 一. 東京 : 砂書房 ; 2006, 24-26.

10) Takahashi F, Koji T, Morita O. Elongation of mouthguard sheet after vacuum forming process by heating conditions. J Sports Dent 2003; 6: 3035.

11) Takahashi F, Koji T, Morita O. Study on mouthguard material-Thickness, relationship between the elongation and the thickness of mouthguard sheet after vacuum forming process-. J Sports Dent 2004; 7: 12-17.

12) Takahashi F, Takahashi M, Koji T, Morita O. 
Study on the elongation and thickness of mouthguard sheets after vacuum forming process - The influence of the height of the working model-. J Sports Dent 2008; 11: 64-70.

13）高橋 睦, 高橋 史, 森田修己. 厚さの異なるシートに おける吸引成形後のマウスガードの厚み。補綴誌 2008; 52: 465-472.

14）高橋 睦, 高橋 史, 森田修己. 吸引成形後のマウスガ ードシートの延び一厚さの異なるシートにおける比較一。 スポーツ歯誌 2008; 11: 45-51.

15）高橋 睦, 水橋 史, 小出 馨, 水橋 亮, 森田修己. シート材の色による成形後マウスガードの厚みの違い. 日補経会誌 2009; 1: 369-402.

16）高橋 睦, 小出 馨, 水橋 史, 水橋 亮, 森田修己. マウスガードシートの熱収縮が成形後マウスガードの延 びと厚さに及ぼす影響。日補綴会誌 2010；2: 61-69.

17）瓦井千穂. カスタムメイドタイプマウスガードの形態の 違いによる応力吸収効果に関する研究。スポーツ歯誌 2004; 7: 36-42.

18）山田純子，前田芳信，米畑有理，佐藤華子. 形成後マウ スガードの厚みについて一形成方法による違い一， スポ ーツ歯誌 2003; 6: 42-45.

19）安井利一，松本 勝. 歯科医師がつくるマウスガード. Dental Products News 2001; 124: 13-15.

20）竹内正敏, 都賀谷紀宏. 口腔内装置作製のためのサーモ フォーミング徹底活用一マウスガード，スプリント，ド ラッグデリバリートレー，インプラント用テンプレート，
可撤式矯正装置 etc. 一. 東京 : 砂書房 ; 2006, 34, 5455.

21）上野俊明，佐々木幸生，隅田陽介。スポーツマウスガー ドハンドブック．東京：医学情報社；2004, 34.

22）武田友孝，月村直樹。マウスガードの製作・調整法。日 本スポーツ歯科医学会編，スポーツ歯科臨床マニュアル， 東京: 医学情報社 ; 2007, 72-73.

23）竹内正敏，都賀谷紀宏。口腔内装置作製のためのサーモ フォーミング徹底活用一マウスガード，スプリント，ド ラッグデリバリートレー，インプラント用テンプレート， 可撤式矯正装置 etc. 一. 東京 : 砂書房 ; 2006, 36-42.

24）竹内正敏. マウスガードの製作・調整法. 日本スポーツ 歯科医学会編, スポーツ歯科臨床マニュアル, 東京 : 医 学情報社 ; 2007, 64-67.

25）大谷隆一郎, 苦瓜明彦, 上松信助, 澤田季子, 有住和浩, 都尾元宣. 新素材マウスガードシートの基礎的，臨床的 研究. 岐歯学誌 2007; 34: 55-63.

26）竹内正敏, 都賀谷紀宏. 口腔内装置作製のためのサーモ フォーミング徹底活用一マウスガード，スプリント，ド ラッグデリバリートレー, インプラント用テンプレート, 可撤式矯正装置 etc. 一. 東京 : 砂書房 ; 2006, 64.

著者連絡先 : 高橋 睦

T 951-8580 新潟県新潟市中央区浜浦町 1-8 TEL: 025-267-1500

FAX: 025-265-8406

E-mail: mutsumit@ngt.ndu.ac.jp 


\title{
Thickness of Mouthguard Sheet after Formation Based on the Shape of the Mouthguard Sheet
}

\author{
Mutsumi Takahashi, DDS, $\mathrm{PhD}^{\mathrm{a}}$, Kaoru Koide, DDS, $\mathrm{PhD}^{\mathrm{a}}$, Fumi Mizuhashi, DDS, $\mathrm{PhD}^{\mathrm{a}}$ \\ and Osami Morita, DDS, $\mathrm{PhD}^{\mathrm{b}}$ \\ ${ }^{a}$ Department of Removable Prosthodontics, The Nippon Dental University School of Life Dentistry at Niigata \\ ${ }^{\mathrm{b}}$ The Nippon Dental University
}

Ann Jpn Prosthodont Soc $3: 135-143,2011$

\section{ABSTRACT}

Purpose: The usefulness of mouthguard to prevent stomatognathic injury during sports depends on the materials and the thickness of the mouthguard. The aim of this study was to investigate the thickness of mouthguard sheet after vacuum forming based on the shape of the mouthguard sheet during heating conditions.

Methods: Cross stripes $(10 \times 10 \mathrm{~mm})$ were printed in mouthguard sheets. The thickness of each cross stripe area was measured by measuring device. The plaster cast was trimmed to the height of $20 \mathrm{~mm}$ at the incisal edge of the upper central incisor and $15 \mathrm{~mm}$ at the medial buccal cusp of the upper first molar. The sheets were heated until they sagged 10, 15, and $20 \mathrm{~mm}$ from baseline by vacuum former. Two shapes of the sheet were compared as follow: Impactguard ${ }^{\circledR}$ grooved sheet (IM-G) and flat sheet (IM-F). The difference in the ratio of change of thickness depending on the shapes of the sheet and the heating conditions was analyzed by two-factor ANOVA.

Results: The change of thickness in the part of the sheet fitted to the anterior teeth and posterior teeth of IM-G was smaller than that of IM-F. The change of thickness was influenced by the heating conditions.

Conclusions: This study suggests that the thickness of mouthguard sheet after vacuum forming was affected by the shape of the sheet, and the grooved sheet could secure the thickness in the part of the anterior teeth and posterior teeth of mouthguard sheet.

\section{Key words}

mouthguard, thickness, shape of the sheet, heating condition 